\title{
ЕКСПЕРИМЕНТАЛЬНО-АНАЛІТИЧНІ ВМІННЯ У СТРУКТУРІ ПРОФЕСІЙНОЇ КОМПЕТЕНТНОСТІ МАЙБУТНІХ ФАХІВЦІВ МЕДСЕСТРИНСТВА
}

\author{
А. Р. Олійникова \\ Тернопільський національний медичний університет \\ імені І. Я. Горбачевського МОЗ Украӥни \\ ННI медсестринства
}

У статті обгрунтовано необхідність формування експериментально-аналітичних вмінь майбутніх медичних сестер у процесі навчання в медичному коледжі. Встановлено відповідність між групами вмінь та виробничими функціями майбутніх медсестер (профілактична, діагностична, лікувальна, технологічна та оцінювальна). Продемонстровано, що експериментальні вміння варто розглядати на різних рівнях (макрорівні, мезорівні, мікрорівні).

\section{EXPERIMENTAL AND ANALYTICAL SKILLS IN THE STRUCTURE OF PROFESSIONAL COMPETENCE OF FUTURE NURSING PROFESSIONALS}

\author{
A. R. Oliinykova \\ I. Horbachevsky Ternopil National Medical University \\ Institute of Nursing
}

\begin{abstract}
The article justifies the need for the formation of experimental and analytical skills of future nurses in the process of studying at the medical college. The correlation between skill groups and production functions of future nurses (preventive, diagnostic, therapeutic, technological and evaluation) was revealed. Besides, it was demonstrated that experimental skills should be considered at different levels (macro-level, meso-level, microlevel).
\end{abstract}

Вступ. Сучасна професійна освіта ґрунтується на реалізації компетентнісного підходу, завданням якого $є$ формування професійної компетентності майбутніх фахівців, в основі якої закладено сукупність знань, умінь і навичок, набутих студентами в процесі професійної підготовки. У контексті компетентнісного підходу проблема розвитку вмінь студентів набуває особливої значущості.

Основна частина. Метою професійної підготовки фахівців медсестринства $є$ забезпечення опанування (досягнення) студентами системи вмінь і набуття відповідних компетенцій, які дають змогу вирішувати типові завдання діяльності під час здійснення певних виробничих функцій [3]. Випускник медичного коледжу повинен бути готовий до виконання таких видів професійної діяльності фахівця, як: профілактична, діагностична, лікувальна, технологічна, оцінювальна. На основі оволодіння вміннями у майбут- ніх медсестер формується готовність до професійної діяльності, тобто професійна компетентність. Це потребувало узагальнення й систематизації умінь, а також вирізнення з них груп, які забезпечили 6 майбутнім фахівцям можливість ефективно виконувати необхідні виробничі функції. Зіставлення змісту вмінь та виробничих функцій наведено в таблиці 1.

Серед сучасних науковців не існує однозначної думки, які саме вміння є визначальними у медичній діяльності. Так, розглядаючи проблему формування експериментальних хімічних вмінь як основу професійної компетентності у студентів медичних університетів, А. Тхакушинова розглядає окреслений процес як важливу сполучну ланку між хімічними знаннями, вміннями, навичками, отриманими студентами в професійній підготовці, та компетенціями, якими вони повинні оволодіти «на виході з університету», щоб бути професійно компетентними [4].

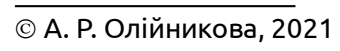

58 ISSN 2411-1597. МЕДСЕСТРИНСТВО. 2021. № 2 
Таблиця 1. Відповідність між групами вмінь та виробничими функціями

\begin{tabular}{|l|c|}
\hline \multicolumn{1}{|c|}{ Група професійних умінь } & Виробнича функція \\
\hline $\begin{array}{l}\text { Організовувати профілактичні щеплення, створювати умови для зберігання бактерій- } \\
\text { них препаратів, розраховувати потреби в бактерійних препаратах для проведення } \\
\text { щеплень }\end{array}$ & Профілактична \\
\hline Здійснювати забір біологічного матеріалу для лабораторних досліджень & Діагностична \\
\hline $\begin{array}{l}\text { Надавати долікарську допомогу при невідкладних станаху внутрішній медицині, } \\
\text { виконувати призначення лікаря }\end{array}$ & Лікувальна \\
\hline $\begin{array}{l}\text { Проводити вибірку, розрахунок дози та введення лікарських препаратів пацієнту, } \\
\text { користуючись медичним інструментарієм }\end{array}$ & Технологічна \\
\hline $\begin{array}{l}\text { Проводити оцінювання результатів досліджень (лабораторних та інструментальних), } \\
\text { стану здоров'я пацієнтів }\end{array}$ & Оцінювальна \\
\hline
\end{tabular}

Експериментальні вміння майбутніх фахівців медсестринства формуються під час проведення хімічного експерименту, проте, враховуючи значущість біологічних дисциплін для медсестер, доцільним $\epsilon$ проведення інтегрованого хімічного експерименту. Експеримент як метод навчального та наукового пізнання використовують у професійній підготовці майбутніх фахівців медсестринства на лабораторних роботах, які вони виконують при вивченні природничо-наукових дисциплін: фізична та колоїдна хімія, медична хімія, біоорганічна хімія, біологічна хімія, а також у процесі вивчення всіх дисциплін професійно-практичного циклу (фізіологія, патофізіологія, клінічне медсестринство тощо). Уміння проводити науковий експеримент і спостереження також $\epsilon$ ключовим у діяльності медичної сестри, а структура навчального експерименту має загальні етапи зі структурою професійної діяльності.

Вирішення будь-яких експериментальних завдань теоретичним шляхом - це математичне моделювання розглянутого явища. Проте можливість теоретичного вирішення завдання обмежується рівнем складності математичної моделі. як правило, складність математичної моделі визначається складністю хіміко-біологічного процесу, який в ній описаний, тому й проблемним є використання такої моделі для розрахунків.

На основі цього, необхідним $є$ виокремлення «умінь-аналогів», які трактуємо як професійні вміння майбутніх фахівців медсестринства. Такими уміннями є: аналіз ролі умов і факторів, що впливають на перебіг досліджуваного хімічного явища або процесу в живому організмі; виявлення найбільш значущих умов і факторів; уявне моделювання: вибір модельного аналога для реального об'єкта чи явища, уявний експеримент і визначення наслідків, їх співвідношення з результатами реального експерименту, визначення можливих альтернатив тощо; інтерпретація результатів експерименту або дослідження, порівняння та узагальнення.

Особливим завданням у процесі вивчення дисциплін природничо-наукового циклу, на думку А. Усової, $\epsilon$ формування експериментальних умінь студентів певних дій та операцій, необхідних для проведення експерименту. Сформованість експериментальних умінь передбачає: самостійне формулювання мети експерименту; формування та обґрунтування гіпотези, що закладається в основу експерименту; виявлення умов, необхідних для проведення експерименту; планування експерименту (визначення спостережень, величин, які необхідно провести та виміряти); розподіл приладів і матеріалів, необхідних для проведення експерименту, складання звітної таблиці тощо; складання експериментальної установки і створення необхідних умов для виконання досвіду; здійснення вимірювань, спостережень; фіксування (кодування) результатів вимірювань і спостережень; математична обробка результатів вимірювань; аналіз результатів і формулювання висновків [5]. Таким чином, діяльність щодо проведення експерименту здійснюється на основі експериментальних умінь, які мають універсальний характер і можуть бути застосовані не лише в навчальній, а також у науковій та професійній діяльності. Отже, узагальнені експериментальні вміння - це вміння, необхідні для проектування, підготовки, проведення та аналізу результатів експерименту.

Виконання будь-якого вміння передбачає розумовий процес, тому формування умінь відбувається таким чином: спочатку формується елементарна дія, підпорядкована певній меті, потім, входячи до складу більш складної дії та перестаючи підкорятися цій меті, елементарна дія стає операцією. Операції, формуючись спершу як цілеспрямовані процеси, можуть набувати форми автоматизованого досвіду. Вже на основі навички можливо сформувати вміння 
або ж готовність особистості до певних дій і операцій на підставі поставленої мети, наявних знань і навичок.

Таким чином, експериментальні вміння потрібно розглядати на різних рівнях: на макрорівні - як узагальнене вміння проектувати, готувати, проводити експеримент і аналізувати його результати в цілому, на мезорівні - як окремі вміння, що входять до складу проектування, підготовки, проведення експерименту та аналізу його результатів (постановка мети, висування гіпотези тощо), на мікрорівні - як дії та операції, необхідні для формування перерахованих умінь.

Натомість, досліджуючи технології професійної освіти, Н. Морева особливу увагу приділяє необхідності розвитку аналітичних умінь, як складової узагальнених умінь майбутнього фахівця, й розглядає їх як нову якість освіти, що забезпечує здатність здійснювати професійну діяльність на основі аналізу в процесі вирішення професійно значущих завдань [2].

\section{СПИСОК ЛІТЕРАТУРИ}

1. Галузевий стандарт вищої освіти України спец. : 6.110102. «Сестринська справа» МОН України. - К., 2012. - 28 c.

2. Морева Н. А. Технологии профессионального образования / Н. А. Морева. - М. : Академия, 2007. - 432 с.

3. Освітньо-кваліфікаційна характеристика Галузевого стандарту вищої освіти України спец. : 8.110102. «Сестринська справа» МОН України. - К., 2007. - 24 с.

4. Тхакушинова А. Т. Формирование обобщенных экспериментально-аналитических умений у студентов
Висновки. Узагальнені вміння у процесі формування професійної компетентності майбутніх фахівців медсестринства передбачає встановлення зв'язку теоретичного і практичного в дисциплінах, уможливлюючи бачення за абстрактними формулами конкретні матеріальні прояви речовин. Безумовно, на основі вивчення дисциплін хіміко-біологічного спрямування формується логічне мислення, здатність до абстрагування й узагальнення, термінологічна пам'ять, асоціативне та образне мислення тощо. Наприклад, логічне мислення фахівця медсестринства проявляється умінням встановлювати причинно-наслідкові зв'язки між будовою, складом і властивостями речовин, прогнозувати поведінку речовин у складі хімічних систем у конкретних умовах, застосовувати стехіометричні закони і закономірності для виконання розрахунків, вирішення експериментальних хімічних завдань.

факультета естествознания университета как основы их профессиональной компетентности : автореф. дисс. на соискание уч. степени канд. пед. наук : спец. : 13.00.08. «Теория и методика профессионального образования» / А. Т. Тхакушинова. - М., 2009. - 24 с.

5. Усова А. В. Новая концепция естественнонаучного образования / А. В. Усова. - Челябинск : Изд-во ЧГПУ, 2002. - 307 c.

Отримано 23.04.21 